\title{
RESEARCH PAPER \\ DEEPENING DECENTRALISATION THROUGH NON-PARTISAN DISTRICT ASSEMBLY SYSTEM IN GHANA
}

\author{
Ronald Adamtey \\ Department of Planning, KNUST, Kumasi \\ radamtey@yahoo.com
}

\begin{abstract}
There is no consensus among scholars as to whether competitive partisan elections at Ghana's district assembly level can help deepen the country's decentralization system. It remains unclear whether a non-partisan district Assembly can work in Ghana. To address this issue, extensive qualitative interviews were conducted with local government officers in five municipalities. An in -depth analysis of the legal framework within which decentralisation reforms are implemented was also undertaken. The study found that a non-partisan district Assembly system seems more of an illusion than reality due to the enduring strength of informal ties, heavy politicization of the district assemblies and numerous challenges confronting the Assembly members. In addition, the constitution still empowers the president to appoint District Chief Executives and onethird of the membership of the district assemblies. It is recommended that in order to deepen the country's democracy, the legal framework need to be revised for competitive partisan elections to be pursued and Assembly members must be paid for their work.
\end{abstract}

Keywords: Decentralisation, devolution, district assembly, informal ties, Ghana

\section{INTRODUCTION}

Political decentralisation in Ghana was shaped by claims in the decentralisation literature that devolution can lead to responsive governance outcomes. The argument that devolution can lead to responsiveness is based on two assumptions. The first assumption is that local politicians are close to the people so they are in a better position to use local knowledge to deliver appropriate needs. The second assumption is that democratic decentralisation can enable citizens at the local level to hold public officers accountable for their actions as they can vote out councilors that they find to be corrupt or inefficient. The pressure of electoral politics can therefore motivate rational public officers to be more responsive to citizens (Ayee, 2008; Agyeman-Duah, 2005; Crook, 2003).

Another claim is that devolution can produce strong democracy and civic awareness, and the development of citizens' political capacity to 
engage with state institutions. This process can lead to increasing the level of civic consciousness of citizens at the local level who might rise to engage in politics at the national level and take charge of national public office. Political decentralisation is also said to enable citizens to participate in the decision making process (Crawford, 2008; Grindle, 2007). Overall, democracy can be strengthened through active participation of citizens which is one indication of good governance.

One of the major requirements for devolution to work is the autonomy of local government bodies (Ayee, 2004a; 2004b; Olowu and Wunsch, 2004). In Ghana, the Local Government Act, 462 of 1993 seeks to achieve autonomy of district assemblies through a nonpartisan Assembly. This can be found in the mode of seeking elections into the Assembly which is enshrined in the Local Government Act 1993 (Act 462). According to the Republic of Ghana (1993), the Mode of seeking election to the District Assembly as provided in Section 7 are as follows:

- A candidate seeking election to a District Assembly or to a lower local government unit shall personally appear before the electorate as an individual, and shall not use a symbol associated with a political party.

- A political party shall not endorse, sponsor, offer a platform to or in any other way campaign for or against a candidate seeking election to a District Assembly or to a lower local government unit.

- A candidate who contravenes subsection (1) commits an offence and on conviction the Electoral Commission shall cancel the nomination of that candidate.

- A political party which contravenes subsection (2) commits an offence and is liable on conviction to a fine not exceeding two hundred and fifty penalty units.
Existing studies on Ghana's decentralisation reforms do not adequately provide answers as to whether these provisions can work and whether non-partisan District Assembly system can be achieved.

\section{RESEARCH METHODOLOGY}

The paper employed a cross-case analysis to examine variations in the ways in which five Municipal Assemblies worked over a period of twelve years from 2000 to 2012. The focus is on the informal ties existing between the $\mathrm{Mu}-$ nicipal Chief Executives and Assembly members. Although other informal ties such as ethnic, old-school, family and neighbourhood relations exist in these cases, the focus of this paper is on political party ties. This covers the devolution that the paper seeks to explore. The work analyses how political party networks can undermine or enhance the desire of the Municipal Chief Executives and their Assembly members (both elected and appointed) to be non-partisan. The data are mainly in the form of narratives of experiences told by the Municipal Chief Executives and the Assembly members.

Employing the case study approach emphasising narratives has the advantage of allowing respondents to express their views and sentiments which often times are missed in other equally good approaches such as statistical analysis (Thomas, 2011; Gerring, 2007). In addition to attending Assembly meetings of all the five cases to understand the influences of political party ties and how they manifest and shape decision making at the Assembly, the existence of these ties were obtained through the administration of questionnaire to 100 Assembly members (20 in each of the five cases) who were randomly selected from both elected and appointed members. The selected members and their five Municipal Chief Executives were asked to indicate their political party affiliation. The registers of memberships of political parties in the municipalities were obtained from the party offices and used to validate the responses from the interviews. 
The information obtained was analysed and results presented in Table 1, showing the existence of political party ties between each of the MCEs and the 20 Assembly members. In order to determine the strength of these ties, a number of steps were followed: First, each of the five cases was represented by letters A, B, C, $\mathrm{D}$, and $\mathrm{E}$ in the first column of the table. Second, the Assembly members interviewed were numbered from 1 to 20 in the second row of the table. Third, the existing ties were indicated and summed up to obtain the total available ties. Fourth, since each case is supposed to score a maximum of 20 (that is when the tie exists between the MCE and all the 20 Assembly members), the total available tie was divided by the maximum score which is 20 to obtain the proportion of existing tie as against the maximum score. Fifth, the values obtained were converted to percentages to obtain the scores in the last column. Sixth, a scale was adopted for the interpretation and determination of the strength of the ties. Political party ties are weak when the score is between 0 and $49 \%$ and strong when it is $50 \%$ and more (Table 1).

\section{THE CONDITIONS UNDER WHICH DEVOLUTION CAN WORK}

Much of the literature regarding devolution has tended to attribute the failure or success of decentralisation reforms to factors at the national level such as the political commitment of national leaders, issues of elite capture of the reform process, and the legal and institutional framework within which local government bodies operate (see, for example, the works of Conyers, 2007; Robinson, 2007; Bardhan and Mookherjee, 2006; Crook and Sverrisson, 2003). There is relatively little work which examines how complete autonomy of devolved bodies within a uniformly decentralised system can be realised particularly in countries such as Ghana where socio-political and cultural issues form the core of social organisation. Current literature does not seem to have critically examined the social and cultural issues such as informal networks existing between actors in decentralised institutions at sub-national level as having the potential to shape both the process and outcome of decentralisation reforms.

The very nature of social organization in Ghana appears to make it practically difficult for devolved and non-partisan Assembly to operate. The importance of social relations is increasingly recognized in other aspects of governance, but very little attention is given to how it can contribute to our understanding of decentralization. Societies in many countries in SubSaharan Africa are highly organized around informal networks: friendship ties, family and kinship relations, ethnic and hometown networks, religious affiliations and political party ties (Crook and Booth, 2011; Leonard, 2009; Blundo et al., 2006). These relationships constitute strong forces that shape many people's behaviour.

So how can informal ties between key officers and elected Assembly members enhance or constrain the realisation of a non-partisan Assembly? Beyond informal ties, are there other factors that point to the inability of Ghana's decentralisation reforms to be non-partisan?

\section{THE ROLE OF INFORMAL TIES}

According to Coleman (1991), informal ties are relationships between people at a personal level. They may include a complex combination of "weak ties (relationship with acquaintances and friends of friends) and strong ties (relationship with friends, relatives and neighbours)" (Granovetter, 1983: 207). Grodeland (2005: 5) has noted that an "informal network is an informal circle of people able to and willing to help each other." The common informal ties in Africa and Ghana are family, kingship, neighbhourhood, religious and oldschool networks. All these ties shape peoples' attitudes and day-to-day decisions are rooted in them (Phinney, 1990; Young, 2004; Hanson, 2004). In reality, the various forms of informal ties overlap in a very complex way. As the focus of this paper is on devolution, the discussion has focused on political party ties. 


\section{Political party ties}

Political party affiliations are the ties that exist among members of a political party. They are so strong that they are likely to strengthen these other ties particularly ethnic relations. For example, in most parts of Africa, there are ethnic groups that are known to have strong allegiance to certain political parties. But this is no surprise as most of the political parties in Africa are rooted in ethnic solidarities (Morrison, 2004; Tignor, 1993; Newbury, 1992). The history of Ghana's political development strongly supports this assertion. Chazan (1982) has noted that:

"Ethnic politics, despite severe vacillations in regime types and ideological predictions, have come to play increasingly prominent roles in Ghanaian politics since independence in 1957. Control of state power has moved from southern Akan groups during the Nkrumah years; through a Ga-Ewe coalition under the National Liberation Council (NLC); the central Akan (Asante-Brong) alliance of Busia; the ethnically more balanced National Redemption Council (NRC) - Supreme Military Council (SMC) constellation; a minority agglomeration with disproportionate northern representation in the administration of the Third Republic; and finally to heavily Ewe-based ruling clique in the Provisional National Defence Council" (Chazan, 1982: 461).

A very important product which is likely to result from informal relations is the issue of trust between members who share these bonds. Trust will be defined in this paper as the situation in which an individual in the network is confident to deal with all others who are members of the network in a transparent and honest way without suspicion or doubt and he or she is convinced that the others deal with him or her in the same way. Trust is needed to sustain informal networks and facilitate the exchange of reciprocal support system within formal relations. 


\section{FINDINGS AND DISCUSSIONS}

The findings from the study are the enduring strength and influence of informal relations, heavy politicisation of the Assembly system, the influences of the political ambitions of the Municipal Chief Executives and a number of challenges confronting the Assembly members. These are presented and discussed next.

\section{Enduring strength of informal relations}

Overall, there were strong informal ties between the Municipal Chief Executives and elected Assembly members. All the five cases recorded the existence of strong ties. For example, both cases $\mathrm{A}$ and $\mathrm{C}$ recorded $70 \%$ and the remaining three cases recorded between $60 \%$ and $65 \%$. This finding shows that inspite of the fact that Assembly members will claim to be non-partisan and that they did not go to the Assembly on political party tickets, all of them have strong attachments and allegiances to political parties. Many political parties are built around long held ideologies and philosophies that are historically enduring. For example, in Ghana, the New Patriotic Party (NPP) is claimed by its members to be rooted in the beliefs and ideologies of J. B. Danquah, Dombo and K. A. Busia. Similarly, the Convention Peoples Party (CPP) has claimed to be championing the vision of Dr. Kwame Nkrumah. Given these claims, it means that members of such parties will uphold these philosophies and act in line with them. Given the overlap between political ideologies and human actions it can be argued that a truly non-partisan Assembly is unlikely to be achieved.

\section{Heavy politicisation of the Assembly}

The Assemblies in all the five cases were found to be heavily politicised. Relationships were affected by the personal political ambitions of the Municipal Chief Executives, Presiding Members, and most Assembly members which resulted in instances of personality clashes among the Chief Executives, Presiding members, and Assembly members. All the Chief Executives sought to hinder the Assembly members they perceived as threats to their per- sonal ambition to become members of parliament, and also push the agenda of their parties in the Metropolitan, Municipal and District Assemblies (MMDAs). All the elected Assembly members said they were unable to influence decisions at the Assembly due to the Chief Executives' manipulation of Assembly business. For example one of the Assembly members indicated that:

"The MCE has managed to get his people to be chairpersons of the important subcommittees. These Sub-committee chairpersons therefore work for the MCE such that issues that the MCE does not like would not pass through to the Executive Committee for consideration and then brought to the general Assembly for deliberation" [Elected Assembly member].

Over $80 \%$ of the Assembly members claimed that they were scared of their Chief Executives because they could cause them to lose their seats. As one of them explained:

"Since 2000, the MCE funded the campaigns of my opponents against me. Unfortunately for him, my people like me, so each time they vote for me that is why I have been in the Assembly for all the three terms. On one occasion, my opponent came to inform me about it. A number of people also came to inform me that the MCE had brought money to be shared for people to vote for my opponent. About five Assembly members have been victims and they all lost their seats."

In one of the cases, the MCE had the power to push the party's agenda due to his party ties and the support of one-third of the members of the Assembly who were government appointees. He also sponsored 10 party members to contest the District Assembly elections in 2006 and six of them won giving him substantial support from the elected Assembly members. $\mathrm{He}$ also got his party member elected as the Presiding Member of the Assembly. All these steps made it easier for him to push his agenda 
through in the Assembly even when some members strongly opposed his decisions.

Similar to the first Municipality, the Presiding Member also played an important role in the second Municipality where he supported the Municipal Chief Executive on most issues. As the Standing Orders provide, the Assembly members are supposed to 'catch the eye' of the Speaker of the Assembly (the Presiding Member) and it appeared that he used this provision to the advantage of the Chief Executive. According to about $80 \%$ of the elected Assembly members, the Presiding Member decided not to 'see' those members who opposed the agenda set by the Chief Executive. Based on events observed during the Assembly meeting, it appears the way in which the Presiding Member steers the meeting shapes the outcome as the Assembly members who were known to be vocal and opposed the Chief Executive were not 'seen' by the Presiding Member even though they raised their hands and sometimes called out the Presiding Member's name to draw his attention. Two examples of projects where the Presiding Member used this strategy to support the Chief Executive's agenda are given below. The first case was narrated by one of the Assembly members:

"The Chief Executive was able to cause the Municipal Assembly to commit an amount of 150,000 Ghana Cedis to supplement an electrification project (street lights) some three months before the Presidential and Parliamentary elections in 2008. He insisted that the 350,000 Ghana Cedis which the central government had brought for the electrification project was inadequate and that he needed the 150,000 Ghana Cedis to pay for labour cost. Most Assembly members opposed this. We suggested that the 150,000 Ghana Cedis should rather be used to complete an office for the National Health Insurance Scheme which was about $60 \%$ complete and had been abandoned for lack of funds. We argued that this would save the assembly from paying the exorbitant rent for office which had been rented for the National Health Insurance Scheme. In spite of our opposition to this, the Chief Executive was able to push this agenda through when it came to voting because the Presiding member refused to see several of us who raised our hands to oppose the motion."

In the second example, all the five government appointees indicated that between 2000 and 2004 and between 2007 and 2008, the award of contracts for the construction of two clinics and one health centre met heavy opposition in the Assembly because there were procedural issues involved that the contract award process did not follow. The Presiding member refused 'to see' those who opposed the motion which was eventually carried through.

All the Assembly members indicated their frustration in the Assembly as their views did not reflect in the Assemblies' programmes. They noted that they saw themselves as 'rubber stamps' in the Assembly to only vote to endorse agendas that were aimed at promoting the aims of the party in power.

\section{Political Ambitions of Municipal Chief Executives}

Political ambitions of many Chief Executives caused them to take a number of steps that undermined the role of Assembly members. Some Chief Executives sponsored candidates to contest seats of incumbent Assembly members who were perceived to be vocal or opponents to them. In most cases, since the Chief Executives had resources and influence, their candidates won. This was a predominant practice in all the five cases. Chief Executives also influenced the election of chairpersons of the various subcommittees. Since the chairpersons of the subcommittees constitute the Executive Committee, the Chief Executive could ensure that members were sympathetic or supportive of his course. The one-third government appointed Assembly members were also likely to support the Chief Executive providing him with significant control over policy outcomes. This asse- 
rtion conforms with the findings of other scholars regarding Ghana's decentralisation programme which is excessive dominance of national politicians in local government business (Abdulai and Crawford, 2010; Crawford, 2009; Crook, 1994).

\section{Challenges of Assembly members}

The prevalence of clientelism, nepotism, and cronyism involved in the Assembly election process was found to undermine the work of the Assembly members. According to the law, the elections are supposed to be non-partisan but in practice this is not the case and they are very expensive to contest. According to the Assembly members, it cost between 1500 Ghana Cedis and 2000 Ghana Cedis to contest an election. Potential candidates have to fund their elections yet Assembly members are unpaid. Most of them complained claiming the process allowed political parties and influential people to secretly fund candidates. This method was employed extensively by all the Chief Executives to unseat incumbent members who opposed them. For example, one of the 'victims' of a Chief Executive's influences explained her case as follows:

"I realised that some of the issues that we raised at Sub-committee level did not appear on the agenda for general Assembly meetings. They ended up at the Executive Committee level. I raised these issues on several occasions at the general Assembly meeting and demanded to know what happened to those issues. I was perceived by the MCE as being anti-government. Most Assembly members believed this because I did not show my political affiliation. The MCE and others propagated the idea that I was against the government. He therefore sponsored a candidate but he lost. During the second elections, the issue of my political affiliation came up again. The MCE sponsored someone against me and I lost."

Interviews with some of the 'beneficiaries' of the MCE's support echoed these observations.
According to one of them, the MCE and a major political party promised him continuous support if he agreed to contest the election and join the Assembly but they had not honoured those promises. Having realised that he was in the Assembly only to vote for the Chief Executive, he has decided to step down out of frustration. This was how he put it:

"I was sponsored by the MCE to contest. He promised that he would continue to support me financially in so many ways. I however regret this because I have been unable to be objective during discussions in the general Assembly. I was forced against my will on some of the issues in the Assembly."

These findings of issues that hamper the effectiveness of elected Assembly members point to two things. First, they further show that the voluntary and non-partisan nature of the job of an Assemblyman might deepen the frustration of Assembly members which would threaten the sustainability of this arrangement. These frustrations can dampen the morale and enthusiasm of potential Assembly persons. Second, the quality of debates in the general Assembly will be poor as they are captured and controlled by the few Assembly members who understand the legal instruments and are able to express themselves fluently in English and local languages. If the MCE is able to capture those few Assembly members who control debates in the Assembly, then he or she can easily steer the Assembly to advance his or her personal political ambitions and party agenda instead of advancing the interests of ordinary people.

The implication here is that the party agenda may not be the same as the interests of ordinary people. It is however possible that when the entire assembly is partisan, elected Assembly members might champion the cause of their electoral areas, similar to what pertains at the national level. In spite of the fact that Members of Parliament are elected on party tickets, many make the effort to seek development for their constituencies. 
POLICY RECOMMENDATIONS

Rethinking competitive elections of all Assembly members and MCEs

The issues about competitive election of all Assembly members and Municipal Chief Executives by citizens on political party tickets raise questions about effectiveness of the debates and preparations that went into the design and formulation of the Local Government Act 462 of 1993. A further debate of the issue seems necessary. As this paper has shown, political parties and powerful elites fund candidates although the process is supposed to be non-partisan and scholars such as Crawford (2010); Awortwi (2010); and Agyeman-Duah (2005) all suggest that competitive election of local government officers can be helpful. Experiences in other countries such as Uganda suggest that vibrant local council elections open avenues for fresh ideas and experience to be introduced into the local governance system at sub-national level. The pressure of competitive elections and the possibility of losing one's job can motivate local government officials to be responsive and accountable to their electorates. But given the claims that elections are heavily influenced by vote-buying, further research is needed to explore the limits of competitive local government elections.

A review of existing legal arrangements for Assembly members to be paid

The job of the Assembly member is voluntary and non-partisan and they are not paid. They are therefore vulnerable to exploitation. This is partly due to the existing legal framework overlooking the fact that non-paid Assembly members can fall prey to powerful interests. The ongoing initiatives and debates among scholars and policy makers around the weaknesses in the Act 462 and the call for a review are laudable and need to be intensified. Act 462 should be revised for Assembly members to be paid monthly salaries from the consolidated fund as any other public sector worker. Although this recommendation can increase the burden on the national budget, it is unlikely to be so if the overall economy performs well and the present economic crises end.

\section{CONCLUSION}

The existing arrangements with ambiguities in the laws are likely to continue for some time. One reason for maintaining this position might be that it allows both central government and sub-national level politicians and bureaucrats substantial control over local government business which might enable them to project personal political ambitions and party agendas. As a result, the commitment to reform might be strong in theory and in policy but this might be weak in practice. This conclusion is based on the premise that informal relations constitute the basic foundation and fabric of the structure of socio-cultural organization in Ghana, and they are likely to undermine efforts geared towards non-partisan Assembly. Repealing the relevant provisions in Act 462 for Assembly members to be elected and paid may not guarantee the development of ordinary people, but these steps can contribute in a significant way towards deepening Ghana's decentralization process and democratic principles.

\section{REFERENCES}

Abdulai, A.-G. and Crawford, G. (2010). Consolidating democracy in Ghana: progress and prospects? Democratization, 17: 26-67.

Agyeman-Duah, B. (2005). Deepening Decentralization in Ghana: Towards Accountable local governance. IN Centre for Democratic Development (Ed). Roundtable discussion. Accra, Centre for Democratic Development.

Awortwi, N. (2010). The Past, Present, and Future of Decentralization in Africa: A Comparative Case Study of Local Government Development Trajectories of Ghana and Uganda. International Journal of Public Administration, 33: 620-634.

Ayee, J. R. A. (2004a). Decentralized Governance and Poverty Reduction at the Local Level in Ghana. Regional Development Dialogue, 25: 71-87. 
Ayee, J. R. A. (2004b). Ghana: A Top-Down Initiative. In Olowu, D. and Wunsch, J. S. (Eds.) Local Governance in Africa: The Challenges of Democratic Decentralization. London, Lynne Rienner Publishers, Inc.

Ayee, J. R. A. (2008). Decentralisation and Governance in Ghana. Regional Development Dialogue, 29: 34-52.

Bardhan, P. and Mookherjee, D. (2006). The Rise of Local Governments: An Overview. In Bardhan, P. and Mookherjee, D. (Eds.) Decentralization and Local Governance in Developing Countries: A Comparative Perspective. Massachusetts, The MIT Press.

Blundo, G., Olivier de Sardan, J. P., Arifari, N. B. and Alou, M. T. (Eds.) (2006). Everyday Corruption and the State: Citizens and Public Officials in Africa, London, ZED Books

Chazan, N. (1982). Ethnicity and Politics in Ghana. Political Science Quarterly, 97: 461485 .

Coleman, J. S. (1991). Prologue: Constructed Social Organization. In Bourdieu, P. and Coleman, J. S. (Eds.) Social Theory for a Changing Society. Boulder, Westview Press.

Conyers, D. (2007). Decentralisation and Service Delivery: Lessons from Sub-Saharan Africa. In Robinson, M. (Ed.) Decentralising Service Delivery? IDS Bulletin, 38(1):18-32

Crawford, G. (2008). Decentralization and the Limits to Poverty Reduction: Findings from Ghana. Oxford Development Studies, 36: 235 -258 .

Crawford, G. (2009). 'Making democracy a reality'? The politics of decentralisation and the limits to local democracy in Ghana Journal of Contemporary African Studies, 27: 5783.

Crawford, G. (2010). Decentralisation and struggles for basic rights in Ghana: opportunities and constraints. The International Journal of Human Rights, 14: 92-125.

Crook, R. C. (1994). Four Years of the Ghana District Assemblies in operation: decentralization, democratization and administrative performance. Public Administration and Development, 14:339-364.

Crook, R. C. (2003). Decentralization and Poverty reduction in Africa: the Politics of local central relations. Public Administration and Development, 23:77-88.

Crook, R. C. and Booth, D. (2011). Conclusion: Rethinking African Governance and Development." IDS Bulletin, 42(2): 97-101

Crook, R. C. and Sverrisson, A. S. (2003). Does Decentralization Contribute to Poverty Reduction? Surveying the Evidence. In Houtzager, P. P. and Moore, M. (Eds.) Changing Paths: International Development and the New Politics of Inclusion. Ann Abor, University of Michigan Press.

Gerring, J. (2007). Case Study Research: Principles and Practices, Cambridge, Cambridge University Press.

Granovetter, M. (1983). The Strength of Weak Ties: A Network Theory Revisited. Sociological Theory, 1:201-233.

Grindle, M. S. (2007). Going Local: Decentralization, Democratization, and the Promise of Good Governance, Princeton, Princeton University Press.

Grodeland, A. B. (2005). Informal Networks and Corruption in the Judiciary: Elite Interview Findings from the Czech Republic, Slovenia, Bulgaria, and Romania. New Frontiers of Social Policy. Arusha Tanzania.

Hanson, K. T. (2004). Landscape of survival and escape: social networking and urban 


\section{Adamtey}

livelihoods in Ghana. Environment and Planning, 37:1291-1310.

Leonard, D. K. (2009). Elections and conflict in Africa: An Introduction. Journal of African Elections, 8:1-13.

Morrison, M. K. C. (2004). Political Parties in Ghana through Four Republics: A Path to Democratic Consolidation. Comparative Politics, 36:421-442.

Newbury, C. (1992). Rwanda: Recent Debates over Governance and Rural Development. In Hyden, G. and Bratton, M. (Eds.) Governance and Politics in Africa. Boulder, Lynne Rienner Publishers.

Olowu, D. and Wunsch, J. S. (Eds.) (2004). Local Governance in Africa: The Challenges of Democratic Decentralization, London, Lynne Rienner Publishers, Inc.

Phinney, J. S. (1990). "Ethnic Identity in Adolescents and Adults: Review of Research." Psychological Bulletin 108 (3): 499-
514.

Republic of Ghana (1993). Local Government Act, 1993 (Act 462). Accra, Ghana Publishing Corporation.

Robinson, M. (2007). Does Decentralisation Improve Equity and Efficiency in Public Service Delivery Provision? In Robinson, M. (Ed.) Decentralising Service Delivery? IDS Bulletin, 38(1): 7-17.

Thomas, G. (2011). How to do your Case Study: A Guide for Students and Researchers, London, SAGE Publications Ltd.

Tignor, R. L. (1993). Political corruption in Nigeria Before Independence. The Journal of Modern African Studies, 31:175-202.

Young, C. M. (2004). Revisiting Nationalism and Ethnicity in Africa. James S. Coleman Memorial Lecture Series. James S. Coleman African Studies Center, UC Los Angeles, James S. Coleman African Studies Center, UC Los Angeles 